\title{
Komunikasi Guru dengan Siswa Membangun Motivasi Belajar Siswa
}

\author{
Wulan Vitasari \\ Email : wulanvitasari05@gmail.com \\ Program Studi Pendidikan Bahasa dan Sastra Indonesia, Universitas Riau
}

\section{Pengantar}

Jika terjadi sebuah jalinan kasih sayang, cinta, ikatan, dan pemahaman satu sama lain dalam sebuah keluarga, membentuk keluarga yang harmonis tidak lain tidak bukan adalah keuntungan dalam menjalin komunikasi yang baik. Komunikasi yang baik memberikan hal yang bermanfaat, bermanfaat bagi banyak orang dan tentunya bermanfaat untuk diri sendiri. Dengan berkomunikasi dapat mengetahui perasaan orang lain yang sedang dekat dengan kita, apakah orang tersebut mempunyai kualitas perasaan yang tinggi terhadap diri kita sendiri. Oleh sebab itu, tidak mungkin seseorang merasakan cinta dan kasih sayang jika tidak menjalin komunikasi yang baik, bahkan bisa dikatakan harmonis. Kalimat-kalimat yang diucapkan membuat seseorang yang merasakan cinta dan kasih sayang tentunya memiliki perasaan nyaman. Sungguh, betapa pentingnya menjalin komunikasi, tidak kenal maka tidak sayang, oleh sebab itu mari kita saling mengenal dengan cara menjalin komunukasi yang hangat dan baik.

\section{Komunikasi}

Komunikasi merupakan peranan penting dalam setiap manusia. Setiap manusia saling membutuhkan satu sama lain, atau disebut makhluk sosial. Perlu komunikasi yang baik antara individu ke individu yang lain untuk menumbuhkan kelancaran dan interaksi yang baik. Akan tetapi, banyak dari setiap individu yang kurang menjalin komunikasi yang baik. Komunikasi yang menumbuhkan silaturahmi yang baik sampai kedepannya. Menjalin komunikasi yang kurang baik mengakibatkan perselisih pahaman atau pertentangan dengan hal yang tidak diinginkan. Jika diketahui, banyak manfaat dalam menjalin komunikasi yang baik salah satunya adalah akan menumbuhkan rasa cinta, kasih sayang, pemahaman, ikatan yang baik, motivasi atau penyemangat, dan bahkan menjadi sebuah ikatan saudara atau keluarga.

Suprapto (2009), Kata komunikasi berasal dari bahasa Latin communicatio yang berarti "pemberitahuan" atau "pertukaran pikiran". Jadi, secara garis besar, dalam suatu proses komunikasi haruslah terdapat unsur-unsur kesamaan makna agar terjadi suatu pertukaran pikiran dan pengertian antara komunikator (penyebar pesan) dan komunikan (penerima pesan). Proses komunikasi dapat di artikan sebagai "transfer informasi" atau pesan dari pengirim pesan sebagai komunikator dan penerima sebagai komunikan. Dalam proses komunikasi bertujuan untuk mencapai saling pengertian (mutial understanding) antara kedua belah pihak yang terlihat dalam proses komunikasi.

Komunikasi dalam semua aspek kehidupan manusia merupakan salah satu kegiatan interaksi antarmanusia yang sangat penting dan seluruh kegiatan manusia dimulai dengan komunikasi, sehingga komunikasi bagaikan urat nadi kehidupan sosial manusia. Mengingat betapa besar peran komunikasi dalam seluruh aspek kehidupan manusia, terutama komunikasi antara guru dengan siswa. Lembaga Ilmu Pengetahuan Indonesia (2007). 
Setiap guru yang menjalankan tugas pembelajaran, ia harus mampu mengatur dan mengelola berbagai aktivitas yang telah direncanakan. Sebelum masuk kelas, guru memang dituntut untuk mempersiapkan berbagai hal yang diperlukan untuk kegiatan pembelajaran. Cara ini bertujuan untuk mempermudah guru dalam melakukan kegiatan pembelajaran baik di kelas atau di luar ruang kelas. Guru yang tidak mempersiapkan segala yang diperlukan dalam pembelajaran dapat menjadikan berbagai aktivitas yang dilakukan tidak terstruktur.Artinya, dalam kapasitas pembelajaran guru harus memiliki perencanaan dan persiapan yang terkonsep dan matang (Mustafa, Hermandra, Suarman, \& Zulhafizh, 2019).

Wiryanto (2000) menjelaskan bahwa, komunikasi dapat didefinisikan sebagai suatu proses, misalnya seorang komunikator menyampaikan pesan berupa lambang-lambang yang mengandung arti, lewat saluran-saluran tertentu kepada komunikan. Dalam pengertian tersebut tampak, proses komunikasi diawali dengan komunikator yang menyampaikan pesan dan diakhiri dengan komunikan yang menerima pesan. Sebagai suatu proses, komunikasi tidak mempunyai titik awal atau titik akhir. Proses komunikasi berlangsung dalam keadaan

dinamik, berkelanjutan, dan berubah-ubah. Agar peristiwa komunikasi mudah dipelajari, kita sengaja menciptakan titik awal dan titik akhir. Untuk menganalisis dinamika proses komunikasi, maka dilakukan pemenggalan proses yang telah dihentikan tersebut.

\section{Komunikasi Guru dengan Siswa}

Wardan (2019) masalah yang timbul dalam proses belajar mengajar salah satunya disebabkan kurangnya hubungan komunikasi guru dengan siswa serta siswa yang satu dengan siswa lainnya sehingga proses interaksi menjadi vakum. Hal ini yang menyebabkan adanya komunikasi yang aktif guru terhadap siswa yang baik. Tugas guru adalah bagaimana harus mendesain agar menciptakan proses belajar yang optimal, mengembangkan interaksi, dan mencapai tujuan yang optimal. Bentuk-bentuk pelajaran selain adanya interaksi di depan kelas, guru juga bisa melakukan proses di luar pokok pembelajaran siswa, misalnya guru dapat menangkap keadaan siswa dan sebaliknya siswa mengajukan berbagai persoalan dan permasalahan yang dihadapinya.

Haqi (2015) mengemukakan bahwa pengajaran pada dasarnya merupakan suatu proses terjadinya interaksi antara guru dengan siswa melalui kegiatan terpadu dari dua bentuk kegiatan, yakni kegiatan belajar siswa dengan kegiatan mengajar guru. Belajar pada hakikatnya adalah proses perubahan tingkah laku yang disadari. Mengajar pada hakikatnya adalah usaha yang direncanakan melalui pengaturan dan penyediaan kondisi yang memungkinkan siswa melakukan berbagai kegiatan belajar sebaik mungkin.Untuk mencapai interaksi belajar mengajar sudah barang tentu adanya komunikasi yang jelas antara guru (pengajar) dengan siswa (pelajar) sehingga terpadunya dua kegiatan yakni kegiatan mengajar (usaha guru) dengan kegiatan belajar (tugas siswa) yang berdaya guna dalam mencapai pengajaran. Sering kita jumpai kegagalan pengajaran disebabkan lemahnya sistem komunikasi, untuk itulah guru perlu mengembangkan pola komunikasi yang efektif dalam proses belajar mengajar. Ada tiga pola komunikasi yang dapat di gunakan untuk mengembangkan interaksi dinamis antara guru dengan siswa, yaitu komunikasi sebagai aksi atau komunikasi satu arah, komunikasi sebagai interaksi atau komunikasi dua arah, komunikasi banyak arah atau komunikasi sebagai transaksi. 


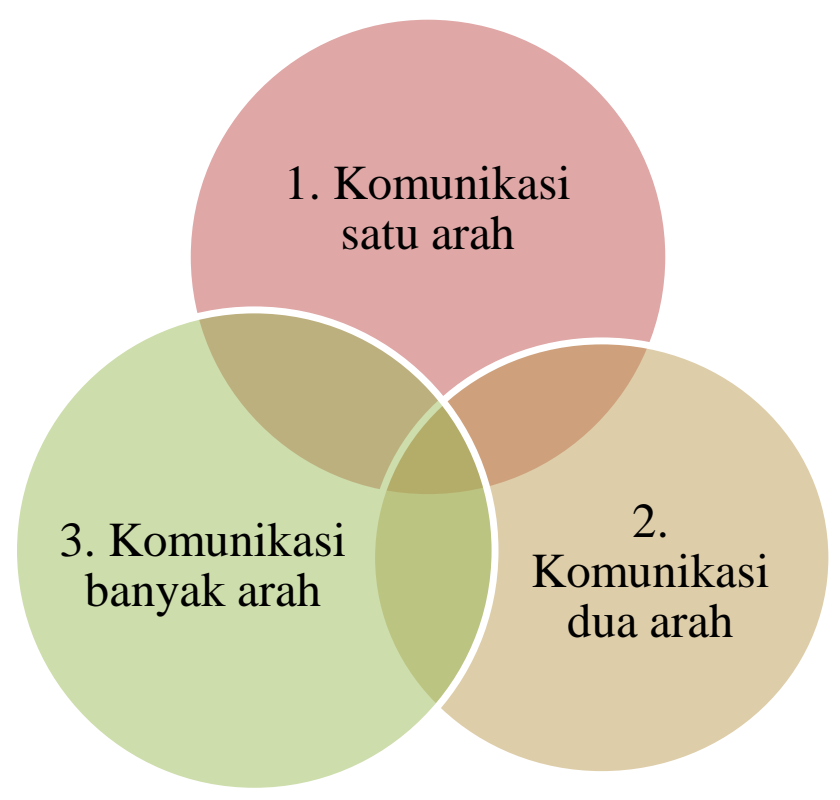

Gambar 1. Pola Interaksi Guru

1. Komunikasi sebagai aksi atau komunikasi satu arah.

Dalam komunikasi ini guru berperan sebagai pemberi aksi dan siswa sebagai penerima aksi misalnya guru menerangkan pelajaran dengan menggunakan metode ceramah, sementara siswa mendengarkan keterangan dari guru tersebut. Apabila jenis komunikasi ini digunakan dominan dapat berakibat kegiatan belajar kurang hidup, Riyadi (2019). Definisi kegiatan belajar kuramg hidup berakibat siswa menjadi pasif atau tidak aktif, dan hanya menunggu interaksi dari guru. Pola interaksi pertama ini cenderung kepada guru yang harus aktif dalam berkomunikasi, sehingga adanya interaksi siswa dengan guru. Komunikasi ini, bersifat menyampaikan pesan dan informasi yang tidak di tanggapi secara langsung, Mulyadi (2006).

2. Komunikasi sebagai interaksi atau komunikasi dua arah.

Riyadi (2019) menjelaskan bahwa komunikasi ini guru dan siswa dapat berperan sama, yakni pemberi aksi dan penerima aksi sehingga keduanya dapat saling memberi dan menerima. Misalnya setelah guru memberi penjelasan pelajaran kepada siswanya, kemudian guru memberi pertanyaan kepada siswanya dan siswa menjawab pertanyaan tersebut. Hal ini dapat menghidupkan suasana belajar. Guru dengan siswa sama-sama berinteraksi satu sama lain, menjalin komunikasi agar meningkatkan pemahaman.

3. Komunikasi banyak arah atau komunikasi sebagai transaksi. 
Yakni komunikasi yang tidak hanya melibatkan interaksi dinamis antar guru dengan siswa tetapi juga melibatkan interaksi dinamis antara siswa yang satu dengan siswa yang lainnya. Misalnya guru mengadakan diskusi dalam kelas.

Dengan adanya tiga pola komunikasi yang jelas dari komunikator kepada komunikan diharapkan dapat memperlancar proses kegiatan belajar mengajar secara efektif dan efisien. Interaksi guru dengan siswa atau peserta didik di dalam kelas maupun di lingkungan sekolah merupakan cerminan dari lingkungan psikologis atau iklim sosial di sekolah. Keharmonisan hubungan antara guru dengan guru, antara guru dengan kepala sekolah, termasuk keharmonisan antara pihak sekolah dengan orang tua merupakan faktor lain yang dapat memengaruhi keberhasilan pengembangan potensi kognitif siswa.

\section{Komunikasi Guru dengan Siswa Membangun Motivasi Belajar}

Guru merupakan cerminan sikap dari peserta didik atau siswa. Salah satunya dilihat dari segi penampilan, fisik, maupun materi. Adanya interaksi atau jalinan komunikasi antara guru dengan siswa yang baik, masuk ke dalam ranah sopan santun dapat menumbuhkan manfaat untuk membangun motivasi atau semangat dalam belajar. Alasannya, jika terjadi komunikasi yang harmonis, guru dengan leluasa memberikan motivasi-motivasi belajar ketika dalam akhir pelajaran atau pada saat proses pembelajaran berlangsung.

Motivasi itu sendiri adalah dorongan atau daya penggerak. Kondisi mendorong individu untuk melakukan suatu kegiatan. Motivasi belajar sangat penting dalam siswa, fungsinya mendorong, mengarahkan, dan menggerakkan siswa dalam kegiatan belajar. Pada hakikatnya motivasi diyakini sebagai penguat, contohnya keinginan yang lebih tinggi dan kuat dalam memasuki ke Perguruan Tinggi, dalam hal ini guru mendorong semangat belajar yang merupakan peran dari kata motivasi, Astuti \& Resminingsih (2010). Motivasi sendiri berasal dari Bahasa Inggris yakni motivation. Namun, perkataan aslinya adalah motive yang juga telah digunakan dalam bahasa Melayu yakni kata motive yang berarti tujuan atau segala upaya untuk mendorong sesuatu untuk mencapai tujuan, dengan tujuan tersebut menjadikan daya utama penggerak bagi seseorang dalam mendapatkan atau mencapai apa yang diinginkannya, baik secara positif maupun negatif, Octavia (2020).

Peranan guru dalam meningkatkan motivasi belajar adalah dengan memberikan motivasi intrinsik pada peserta didik atau siswa. Cara yang dapat dilakukan meliputi pemberian penghargaan bagi peserta didik yang berhasil menjawab soal atau menyelesaikan pekerjaannya dengan berbentuk hadian-hadiah kecil yang dapat menumbuhkan semangat dari dalam diri peserta didik. Selain itu, guru juga harus melakukan pembelajaran yang menyenangkan dan menggunakan media pembelajaran yang menarik perhatian peserta didik, sehingga tidak ada perasaan bosan atau jenuh yang dirasakan oleh siswa.

Apabila guru telah berhasil dalam meingkatkan motivasi belajar, maka dalam proses pembelajaran, peserta didik akan menunjukkan ciri motivasi. (Sardiman, 2012 (dalam buku Astawa, 2018), ciri motivasi meliputi, tekun dan serius dalam mengerjakan setiap tugas yang diberikan, tidak mudah putus asa dalam menghadapi kesulitan, menununjukkan minat belajar, senang belajar mandiri, cepat bosan dengan tugas yang sama-sama berulang, mampu 
mempertahankan pendapatnya dalam diskusi, rajiin dan penuh semangat dalam belajar, dan gemar memecahkan masalah yang dihadapi.

Apabila minat dan motivasi siswa maka penting untuk memberikan pembinaan dan dorongan dalam menumbuhkan minat dan motivasi siswa dalam pembelajaran contohnya dalam mata pelajaran bahasa Indonesia. Jika minat dan motivasi siswa dalam pembelajaran bahasa Indonesia tinggi maka menghasilkan siswa yang komunikatif dan menguasai penggunaan bahasa dengan baik. Sardiman menyatakan bahwa motivasi belajar merupakan suatu keinginan atau dorongan untuk belajar (Zulhafizh, Atmazaki, dan Syahrul, 2013). Jika anak memiliki motivasi dalam belajar maka akan menghasilkan belajar yang maksimal dan anak paham terhadap pembelajaran bahasa Indonesia sebab anak diberi dorongan yang dapat membangkitkan semangat oleh lingkungan sekitarnya. Selain itu, motivasi belajar dapat diamati dari kegiatan dan hasil belajarnya. Siswa yang memeroleh hasil belajar yang baik karena kegigihannya menunjukkan motivasi belajar yang tinggi. Siswa yang memeroleh hasil belajar yang rendah dapat pula disebabkan oleh motivasi belajar yang rendah.

Haqi (2015) mengemukakan ada berbagai macam motivasi belajar. Motivasi belajar merupakan kondisi psikologis yang mendorong seseorang untuk melakukan aktivitas belajar untuk mengetahui macam-macam motivasi akan dapat dilihat dari segi intrinsik dan ekstrinsik.

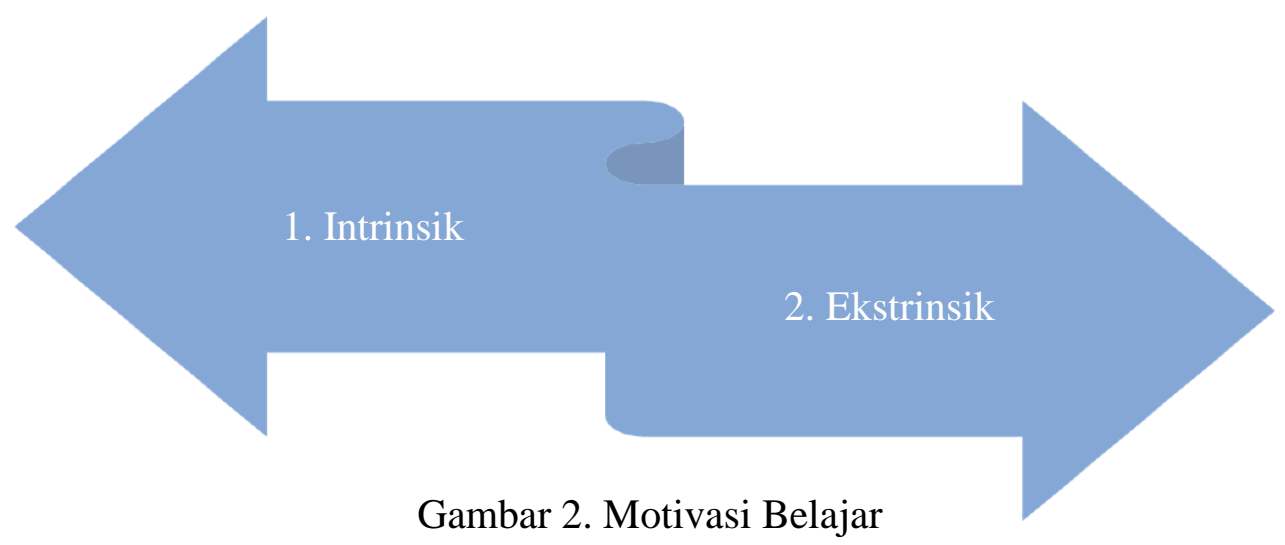

1. Motivasi Belajar Intrinsik

Maksudnya adalah motif-motif yang menjadi dasar aktif atau berfungsinya tidak perlu dirangsang dari luar karena dalam setiap individu sudah ada dorongan untuk melakukan sesuatu. Jenis motivasi ini timbul sebagai akibat dari dalam diri individu sendiri tanpa ada paksaan, dorongan orang lain, tetapi atas kemauan sendiri. Misalnya anak mau belajar karena ingin memperoleh ilmu pengetahuan dan ingin menjadi orang yang berguna bagi nusa, bangsa dan negara. Oleh karena itu ia belajar tanpa ada suruhan dari orang lain. Ada beberapa hal yang dapat merangsang timbulnya motivasi intrinsik, diantaranya disebabkan:

a. Adanya kebutuhan disebabkan karena adanya kebutuhan terhadap suatu hal, seseorang akan terdorong berbuat atau berusaha melakukan sesuatu sehingga terpenuhi kebutuhannya. 
b. Adanya kemajuan tentang adanya tentang diri sendiri, dengan mengetahui hasil belajar, atau prestasi yang dicapai baik itu terbentuk kemajuan atau kemunduran dapat mendorong untuk belajar untuk lebih giat lagi. Terlepas prestasi yang diraihnya itu baik atau justru sebaliknya prestasinya berupa kemunduran, hal ini akan membawa pengaruh semangatnya dalam melakukan kegiatan belajar mengajar. Kalau prestasi bagus ia akan terdorong untuk mempertahankan prestasinya, dan apabila prestasinya sedang menurun ia akan berusaha memperbaikinya.

c. Adanya aspirasi atau cita-cita. Cita-cita biasanya akan timbul karena adanya keinginan diri sendiri untuk mencapai sesuatu. Maka cita-cita diri merupakan pembangkit semangat belajar anak.

\section{Motivasi Belajar Ekstrinsik}

Motivasi ekstrinsik adalah motivasi yang aktif dan berfungsinya karena adanya perangsang dari luar Jenis motivasi ini timbul sebagai akibat pengaruh dari luar individu atau karena adanya ajakan, suruhan atau paksaan dari orang lain, sehingga dengan adanya kondisi demikian akhirnya ia mau melakukan sesuatu untuk belajar. Sebagai contoh: seseorang mau belajar karena ia disuruh oleh orang tuanya agar mendapat peringkat di kelasnya. Motivasi ekstrinsik lebih kuat dan tahan lama dibandingkan dengan motivasi intrinsik. Sebab melalui motivasi intrinsik, dimulai belajar dan diteruskan berdasarkan golongan dari individu atau siswa sehingga mereka belajar tanpa disuruh. Meskipun demikian motivasi ekstrinsik tidak dapat diabaikan. Ia harus ditumbuhkan dan dirangsang sehingga menimbulkan motivasi intrinsik. Untuk dapat menumbuhkan motivasi dalam belajar, Nasution mengemukakan pendapatnya, bahwa hal tersebut dapat dilakukan seperti dengan "memberi angka, hadiah, saingan, hukuman dan sebagainya.

Aktifitas belajar yang disertai motivasi, akan menghasilkan prestasi yang baik, karena semakin kuat motivasi yang diberikan, semakin berhasil pengajaran itu. Motivasi menentukan intensitas usaha anak belajar. Demikian sebaliknya. Bila motivasi belajar rendah, dengan sendirinya hasil belajar kurang memuaskan. Dengan demikian semakin kuat motivasi belajar, maka semakin baik pula prestasi belajar yang akan dicapai siswa. Mengingat begitu pentingnya motivasi dalam belajar mana seseorang pendidik/guru harus sebisa mungkin mengembangkan semangat belajar siswanya.

Komunikasi sangat berperan karena dalam proses belajar terdapat unsur yang saling mempengaruhi komunikasi yang dilangsungkan dengan sadar dengan keinginan untuk mengetahui dan mempengaruhi, yang mempengaruhi disini mengandung makna edukatif. Dengan komunikasi. Proses perubahan tingkah laku akan terjadi dan dari tidak tahu menjadi tahu, dan tidak paham menjadi paham.

Dengan demikian komunikasi dapat menimbulkan efek sesuai dengan tujuan yang diharapkan, yaitu menumbuhkan motivasi belajar siswa sehingga prestasi siswa akan menjadi baik. Untuk mengembangkan kemandirian siswa, diperlukan suatu kondisi yang memungkinkan siswa belajar secara efektif semakin banyak siswa melakukan komunikasi maka semakin dalam pengetahuannya semakin banyak siswa melakukan komunikasi, maka 
kecakapan dan pengetahuan yang dimilikinya dapat semakin dikuasai dan semakin mendalam, karena komunikasi yang telah dilakukan akan membawa ke tingkat yang lebih baik. Dengan demikian secara kronologi dapat dikatakan bahwa kreativitas komunikasi yang diberikan guru terhadap muridnya. Maka semangat siswa dalam belajar juga tinggi sehingga akhirnya akan mempengaruhi hasil belajar yang baik pula.

\section{Penutup}

Komunikasi antar sesama merupakan suatu proses hubungan satu sama lain berlangsung. Sebagai guru harus tahu bagaimana cara menjalin komunikasi dengan siswanya, agar pembelajaran berjalan dengan aktif, kreatif, dan tidak membosankan. Setiap manusia penting adanya motivasi dari hidupnya, sama halnya dengan peserta didik yang perlu motivasi dari dalam dirinya. Jika anak memiliki motivasi dalam belajar maka akan menghasilkan belajar yang maksimal dan anak paham terhadap pembelajaran bahasa Indonesia sebab anak diberi dorongan yang dapat membangkitkan semangat oleh lingkungan sekitarnya. Selain itu, motivasi belajar dapat diamati dari kegiatan dan hasil belajarnya. Siswa yang memeroleh hasil belajar yang baik karena kegigihannya menunjukkan motivasi belajar yang tinggi. Siswa yang memeroleh hasil belajar yang rendah dapat pula disebabkan oleh motivasi belajar yang rendah.

\section{Daftar Pustaka}

Astawa, I Gusti Lanang Gede Putra., Luh Putu Cakrawati., Erri Trisna Nurhayana., \& I Wayan Ardika. (2018). Inovasi Pembelajaranku. Bali : Yayasan Er Institute.

Astuti, Dra. Endang Sri, Dra. Resminingsih. (2010). Bahan Dasar untuk Pelayanan Konseling pada Satuan Pendidikan Menengah Jilid 1. Jakarta : Grasindo.

Haqi, Luqman. (2015). Pengaruh Komunikasi antara Guru dengan Siswa terhadap Motivasi Belajar Siswa Kelas V Mi Matholi'ul Huda 02 Troso Jepara Tahun Pelajaran 2015. Skripsi Mahasiswa.

Lembaga Ilmu Pengetahuan Indonesia. (2007). Problem Komunikasi antara Aparat Polri dan Penunjuk Rasa. Majalah Ilmiah Komunikasi dalam Pembangunan Vo. 10, No. 2.

Mulyadi., Royanti., Diana Novianti., \& dkk. Pendidikan Lingkungan dan Budaya Jakarta. Jakarta : Pt. Gramedia Widiasarna.

Mustafa. M. N., Hermandra., Suarman., \& Zulhafizh. (2019). Manejerial Pembelajaran Kreatif: Menjadi Guru Jitu. Yogyakarta : Mirra Buana Media.

Octavia, Shiply A. (2020). Motivasi Belajar dalam Perkembangan Remaja. Yogyakarta : Deepublish.

Riyadi, Irwan. (2015). Model Pembelajaran Berbasis Metakognisi untuk Peningkatan Kompetensi Siswa pada Mata Pelajaran IPS. Yogyakarta : Deepublish. 
Suprapto, Tommy. (2009). Pengantar Teori dan Manajemen Komunikasi. Yogyakarta : MedPress.

Wiryanto. (2000). Teori Komunikasi Massa. Jakarta : Pt. Gramedia Widiasarna.

Wardan, Khusnul. (2019). Guru sebagai Profesi. Yogyakarta : Deepublish.

Zulhafizh, Atmazaki, S.R. (2013). Kontribusi Sikap dan Motivasi Belajar Siswa terhadap Hasil Belajar Bahasa Indonesia. Jurnal Bahasa, Sastra dan Pembelajaran Volume 1 Nomor 2, 1, 14-26.

Data Penulis

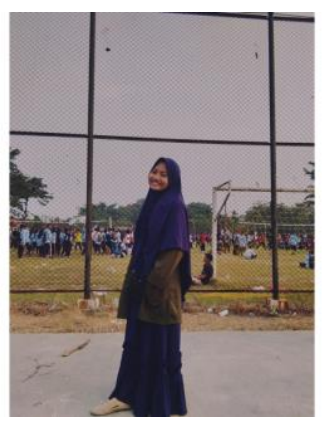

Wulan Vitasari, lahir di Tanjung Beludu, 31 Desember 2000. Ia merupakan anak pertama dari 3 saudara. Pada tahun akademik 2018, Ia melanjutkan studi pada strata satu Jurusan Pendidikan Bahasa dan Seni di Program Studi Pendidikan Bahasa dan Sastra Indonesia FKIP Universitas Riau melalui jalur PBUD (Penulusuran Bibit Unggul Daerah), Universitas Riau merupakan salah satu Universitas yang ia minati sejak Madrasah Tsanawiyah. Pada saat ini, saya sudah semester 5 dan sudah menerbitkan berbagai macam karya buku, seperti novel dan puisi. Ia juga pernah menjuarai dalam acara Olimpiade HIMAPEFSI yaitu lomba cerpen dengan juara 3 pada tahun 2019. Beliau berharap dapat menyelesaikan studinya dengan cepat di strata 1 Jurusan Pendidikan Bahasa dan Seni di Program Studi Pendidikan Bahasa dan Sastra Indonesia FKIP Universitas Riau.

Kontak : 081373152793

Hp/wa : 081373152793

Email : wulanvitasari05@gmail.com 